\title{
システムトラスによる中国大連タワーの構造設計と技術開発 STRUCTURAL DESIGN AND TECHNICAL DEVELOPMENT OF SYSTEM TRUSS FOR THE DALIAN TV TOWER IN CHINA
}

\author{
岩田。衛，川合廣樹**，和田章***, 矢木 寛****, \\ 原田昭穂****, 白井貴志**** \\ Mamoru IWATA, Hiroki KAWAI, Akira WADA, Hiroshi YAGI, \\ Akiho HARADA and Takashi SHIRAI
}

\begin{abstract}
This paper first explains the background for the adoption of System Truss. for the Dalian TV Tower in China as well as the determination of design load and allowable stress.

The section on the structural design states the analysis model, member design, self-induced vibration of pipe member, etc. Explained next are the wind tunnel test conducted to determine velocity pressure, and the stability analysis conducted to estimate the ultimate condition of the Tower.

Furthermore, the material and strength characteristics of System Truss components are explained, particularly the production test of large-diameter bolts. Finally, the paper reports on the construction techniques.
\end{abstract}

Keywords : system truss, tower, structural design, construction technique システムトラス，タワー，構造設計，施工技術

\section{1. 序 論}

建築物は土木施設と同様に，建設された場所に固定さ れて使われるため, 建設地の地盤状態, 地震活動度, 強 風，建設地域のもつ技術などの風土を良く知った上で， その構造設計を進めるべきである。過去から使われてき た設計方法，施工方法には，その方法の正しさについて 確固たる説明はできなくても，その建設地の風土に適合 し，その構造が長い年月，傾くこともなく，地震にも耐 え，強風の中にあっても大きく摇れたり，壊れたりする ことがなかったという実績のもつ重みがある。同じよう な場所に同じような建物を作るとき，過去からの経験に 基づき少しずつ改良を重ね，新しい挑戦を試み，その適 用範囲を広げていくことが，近代科学が確立される以前 の技術の発達であったといえる。近代科学が確立されて からは，これらの経験と実績を積み重ね続ける上に，地 震, 台風などの外力や地盤; 水位, 気象条件のような設 計条件に関する調查研究，それらに対する構造のモデル 化や解析，あるいは動的外力に対する応答の解明，構造 物の強度や変形能力に関する研究, 新しい材料や構法の
開発をすることによって, 現在の構造設計法が成り立っ ている。

‘しかし，日本の現状を振り返ると，過去の経験や調査 研究を反映して作った建築基準法, 同施行令, 建築学会 の各種規準，建築センタ一の指針に代表される設計環境 の固定した標準化が，設計の自由度を狭めているように 思われ，このよううな設計環境の中にいるため，各種の設 計条件, 構造物の力学的性質等を原点まで戻って見直す ことが忘れられているように感じられる。実際の建築物 の設計や施工を進める際には，学問だけでは説明のでき ない設計者の判断や決断が必要である。しかし，上記の 基準や国内の多くの建築奏績が実務標準を作ってしま い, 設計者が各種のデータに基づき判断や決断をすべき 部分を侵していると考える。このために，ある程度の実 際的な調查や研究の方法が確立されてきたにもかかわら ず，設計上に必要な項目について，設計者がプロジェク トごとに自ら再度調べたり，実験を行ったりすることが 少なくなっている。また以前に設計された同様の建物の 設計方法を，建設地の風土やプロジェクト固有の条件に

\footnotetext{
* 新日本製鐵株式會社・工博

** 株式会社日建設計・工修

*** 東京工業大学 教授.工博

****,新日本製鐵株式會社・工修。
}

Nippon Steel Corporation, Dr. Eng.

Nikken Sekkei, M. Eng.

Prof., Tokyo Institute of Technology, Dr. Eng.

Nippon Steel Corporation, M. Eng. 
対して見直すことのないままに，そのまま用い，構造設 計を定形的な仕事にしようとする動きが強い。

ここでは，中国遼寧州大連市に，システムトラス”を 用いて建設した鉄骨タワーの設計から施工に至るまでの 調査研究と技術開発をまとめて報告する。海外，特に大 型の建築物が作られたことのない地域においては，新し い構法による建築物を建設しようとするときに, 上述し たような経験や実績がなく, 現地の構造設計基準も整備 されていない。本報告は，構造設計に当たって基本的に 考えるべきこと，現在の技術によって判断できること， 設計者の判断によって実行すべきことなどについて見直 す一つの例になると考える。

本報告では，まず，タワーの計画概要と構造計画を説 明し，タワーの構法としてシステムトラスを採用した経 緯, および設計荷重と許容応力の設定について述べる。 構造設計では, 要求条件, 解析モデル, 設計応力, 部材 設計, パイプ部材の自励振動, 柱脚部の設計に言及する。 次に, 強風設計の速度圧, 風力係数等を設定するために 行った風洞実験，およびタワーの終局状態を推定するた めに行った弾塑性解析による安定解析について述べる。 さらに設計に用いたシステムトラス部品の材料と強度の 特性に触れ，特に太径ボルトの仕様を決定するための製 造実験について述べる。終わりに，システムトラスによ るタワーの施工技術を報告する。

\section{2. 計画概要}

タワーは，大連市内にそびえる緑山（海抜 $175 \mathrm{~m}$ ）の 頂部の鞍を幅 $70 \mathrm{~m}$, 長さ $150 \mathrm{~m}$ にわたって切り崩し整 地した敷地に計画, 建設された（写真一1）。

タワーは, 図-1に示すように, システムトラスによ る塔本体, コアシャフト,ゲインタワー(電波発信塔) から構成され，高さは $192 \mathrm{~m}$ である。塔本体の頂部に は回転レストランが設置されるので，平面形は円に近い 正 12 角形の形状である。タワーの外径は約 $24 \mathrm{~m}$ であ る。

\section{3. 構造計画}

構造計画に際しては, 問題解決のための思考環境を白 紙に近い状態からスタートさせなければならない。ここ で考えるべき問題の基本は, 大連の緑山の山頂が建設地 であること, 日本の技術の適用方法, 観光電波塔, シン ボル性, 高さ, 荷重と許容応力, コスト, 施工法などで ある。

\section{1 タワーの形状および構法}

タワーの構法としては,古くは組石造や木造もあるが, $100 \mathrm{~m}$ を超えるものは鉄筋コンクリート造または鉄骨造 に限られている。地震のないところにあるカナダの CN タワーやモスクワタワーのような $500 \mathrm{~m}$ を超える夕

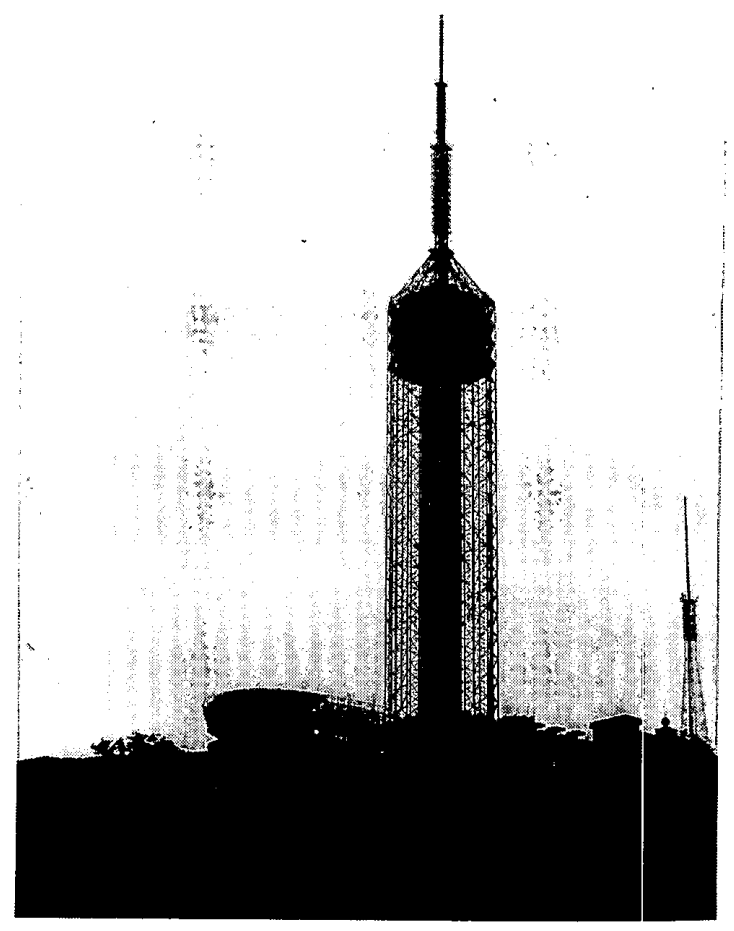

写真一1 タワー全景

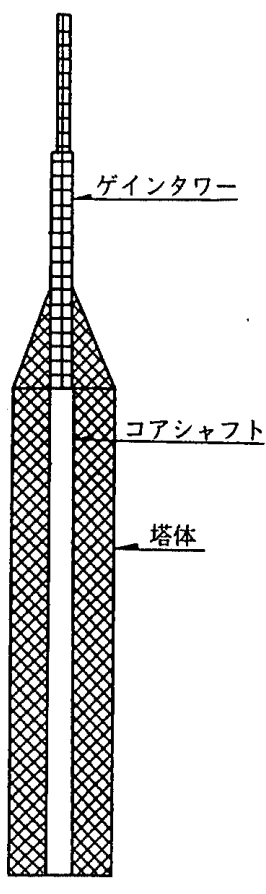

図一1 タワー概略図

ワーでは, 風に対する質量効果の優位性から, 鉄筋コン クリート造のものが建設されている。

大連タワーは $200 \mathrm{~m}$ 級の鉄骨造のタワーとして計画 された。鉄筋コンクリート造では, 大連で予想される地 震に対し不利であると判断されたからである。鉄骨造の タワーの中で, 最近の日本で建設されているような, 鉄 骨の外側をガラスやメタルで被せた案も検討された。し かし, 受風面積を低減して風荷重を娍らし, 緑済設計を 


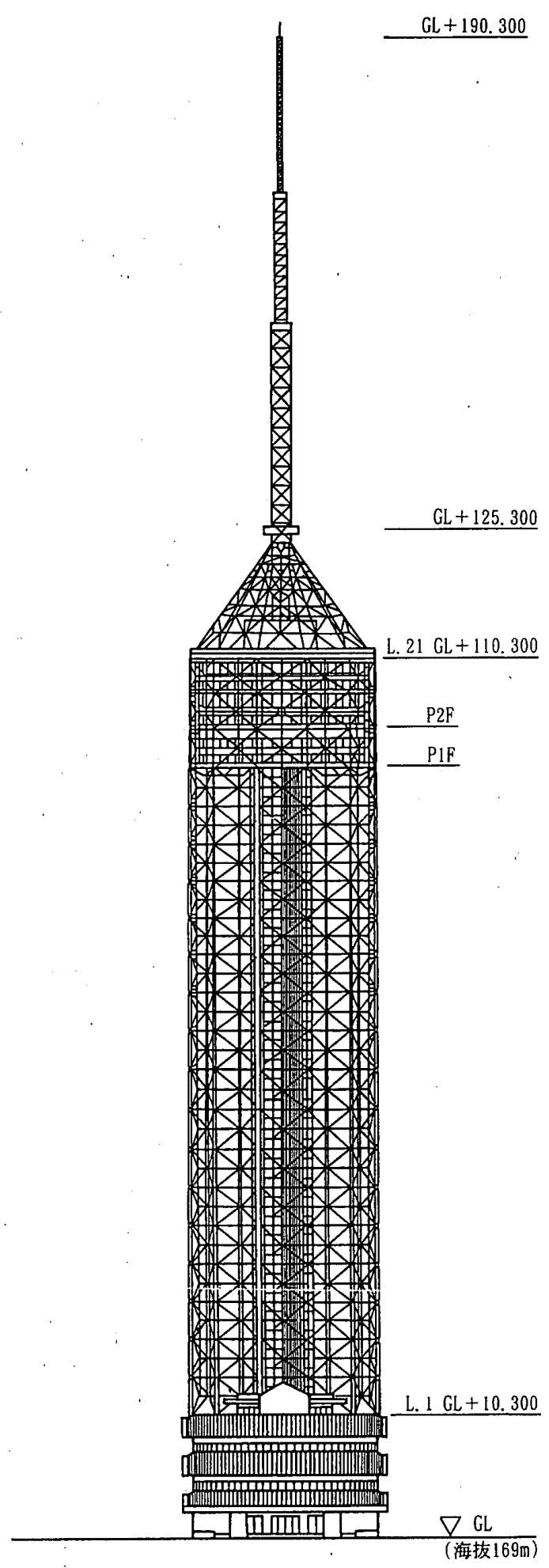

図一2 タワー立面図

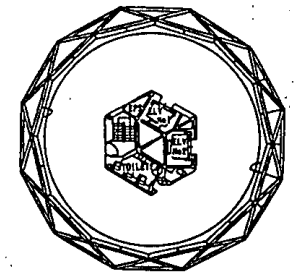

P $1 F$

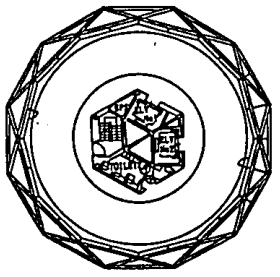

P $2 \mathrm{~F}$
図一3 タワー平面図
図ろうとしたこと，また鉄骨の亜鉛メッキによる防錆技 術の信頼性が向上したことから，露出鉄骨案とした。こ のような背景に加えて座屈耐力が優れていることから， 図一 $2 ， 3$ に示すようなパイプによる立体卜ラスが取り 上げられた。

\section{2 システムトラスの採用}

パイプによる立体トラスのタワーとするにあたって， ジョイントの信頼性を検討し，一本ボルトによるシステ ムトラスを採用することに決定した。それは，建設現場 が山頂での作業であり, 熟練労働者もほとんぼいないこ とから，現場溶接や多本数の高力ボルトを用いた接合方 法に比較して，作業性のよい太径の一本ボルトによる接 合方法の方が，現場において，少ない接合箇所の少ない 本数を管理すればよいこと，およびボルトの製造本数も 少ないため, 製造管理も容易であることによる。そこで, 大連タワーでは，一本ボルトによるシステムトラスが総 合的に信頼性が高いと判断したからである。このために, 後で述べるような仕様のもとに, 太径ボルトの品質管理 および素材の選定にあたって，工場における全数検査を 行った。

システムトラスは，先端技術的工業製品であり，コス トが部品ごとに明確である。このため; 当時の中国のス ローガンの一つであった「先進性」に，このシステムト ラスが合致したことも，採用された要因としてあげられ る。

\section{3 荷重と許容応力}

構造体の安全性は, 設計に用いた荷重の確率的危険性 と実際にできあがる構造系の耐力の信頼性の相互関係か ら決定される。

タワーが受ける外力として, 特に風荷重が問題であっ た。風荷重の設定に際しては，風圧レベルと実効風圧力 に対しては信頼性の高い風洞実験を実施し，危険確率を 確かなものになし得る。しかし，大連のような観測デー 夕が少ない地域の風速については，確かな危険確率が設 定できないため，風圧力に対する許容応力の割増に安全 を見込まなければならない。

設計基準風速は, 3 秒間瞬間最大風速の 50 年再現期 待値 ${ }^{2}$ として， $45 \mathrm{~m} / \mathrm{s}$ を採用した。大連地区の高さ 105 $\mathrm{m}$ にある観測所で 1949 年から 1987 年までの 38 年間に 観測された 3 秒間瞬間最大風速は 1986 年に $35 \mathrm{~m} / \mathrm{s}$ が 1 度だけ測定され，その他の年はすべて $20 \mathrm{~m} / \mathrm{s}$ 以下であっ た。このことからは，設計基準風速を $45 \mathrm{~m} / \mathrm{s}$ と決めた ことは，十分安全側であると考えることができる。しか しながら，観測資料の信頼性に疑問が残ること，大連が 黄海と渤海に囲まれたところに位置しているとはいえ， 長年の間には設計基準風速が $50 \mathrm{~m} / \mathrm{s}$ 程度の大型台風が 上陸する可能性も皆無ではないこと等の不確定要因が大 きいとの判断から, 風圧力に対する許容応力の割増を日 
本で用いられている長期許容応力度と短期許容応力度の 比である 1.5 倍でなく，1.25 倍に押さえ，構造耐力に $20 \%$ の余力を持たせ, 設計基準風速 $50 \mathrm{~m} / \mathrm{s}$ にも対処で きるようにした。

地震力に対する設計条件は，中国の耐震荷重基準烈度 8 の地域であることを踏まえて，地上加速度 $100 \mathrm{gal} に$ 対して弾性範囲にあり, 最大 $200 \mathrm{gal}$ の加速度に対して 崩壊しないことであった。ELSENTRO NS 1940.5.18 とTAFT EW 1952.7.21を用いた地震応答解析の結果, トップヘビーの形状でありながら,重量が小さいために， $100 \mathrm{gal}$ の地上加速度に対して，タワ一構造体に生じる 㐫力は風荷重時の応力に比べ $40 \sim 50 \%$ 程度であり， $200 \mathrm{gal}$ の加速度に対してもタワー構造体は弾性範囲に とどまり, 変形量も特に問題とされるほどにはならな かった。日本の超高層ビル構造のように弾塑性状態を考 慮した設計でなく，強度設計を行うことが可能であり， 地震に対しては十分安全であると判断した。

\section{4. 㗕造設計}

4.1 設計条件

（1）風荷重; $45 \mathrm{~m} / \mathrm{s}$ （設計基準風速，ただし 3 秒間瞬 間最大風速)

（2）地震荷重; 中国耐震荷重基準烈度 8（地上加速度 $200 \mathrm{gal}$ 相当)

（3）水雪荷重; 着水厚 $5 \mathrm{~mm}$

（4）タワーの変形制限; 通信機能上からゲインタワー 頂部の最大変形角は $\delta / \mathrm{h}=\tan 0.5^{\circ}$

(5) 地耐力; $200 \mathrm{tf} / \mathrm{m}^{2}$

\section{2 解析モデル}

システムトラスによる塔本体，コアシャフト，ゲイン タワーからなるタワー構造体全体についての立体解析モ デルを構築した。節点数 1270 , 部材数 2910 のモデル に対し, 風荷重, 鉛直荷重を, 節点荷重と部材間荷重と して作用させた。

タワー構造体の下部の一般施設部分は, 鉄筋コンク リート造で設計した。この部分の実施設計は中国航天部 (航空宇宙局) の施設課が担当したので，タワ一構造体 の直下部分の設計は, 柱脚部の応力解析結果に基づき中 国の設計基準によって設計した。

\section{3 設計応力}

設計応力は，日本で行っている設計の考え方を用い， 以下の組み合わせ忍力を設定した。

$G ：$ 固定荷重

$P:$ 積載荷重

$W$ : 風荷重

$S:$ 水雪荷重

(1) $G+P$

(2) $G+W$
(3) $G+P+W$

(4) $G+0.5 S+0.7 P+0.25 W$

（1）は長期，その他は短期荷重と考える。（4）に示し たすべての荷重が同時に作用する組み合わせにおける荷 重係数は次のように考えて決めた。

（i）短期荷重に対して，水雪荷重を $50 \%$ に低減する。

（ii）積載荷重が等分布に広い領域に分布する場合は, $70 \%$ に低減する。

（iii）風荷重は, 他の荷重亡組み合わせる場合, 再現期 間を毎年のものと考え，25\%に低減する。

発生最大軸力は（2）の場合に生じ，縦弦材て $300 \mathrm{tf,}$ 斜材で $45 \mathrm{tf}$ であった。この場合のベースシアーは 315 $\mathrm{tf}$ ，転倒モーメントは $24000 \mathrm{tfm}$ であった。

\section{4 部材設計}

部材の設計は，日本建築学会の諸規準 ${ }^{31,41}$ および建築 基準法，同施行令，日本建築センターの指針 ${ }^{5}$ に書かれ ている方法を用いて行った。ただし，鋼材の風荷重時の 許容応力度は，中国大連市に対して設定した風荷重の危 険確率が大きいため，先にも述べたように短期筝容応力 度を長期許容応力度の 1.25 倍とした。塔本体部分のパ イプ部材，ノードおよびボルトは，システムトラスト部 品（図一4）の中から定められた設計手順に基づいて選 定しだ!。システムトラスの最大部品は，ノード：U 490 (外径 $490 \mathrm{~mm}$ ), パイプ：406.4 $6 \times 19$ ，ボルト：M 95 であった。

コアシャフトは, 非常にスレンダー（直径と高さの比

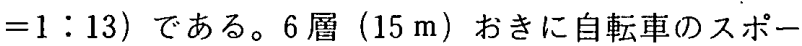
ク状のパイプの引張材で塔本体であるシステムトラスに 緊結することにより，コアシャフトにかかる風㞋力はす べて外周のシステムトラスに負担させるようにした。な お,コアシャフトの骨組みは, 通常のパイプと形细によっ て構成し，高力ボルト接合によった。

ゲインタワーは全長約 $65 \mathrm{~m}$ で，3段で構成され，そ

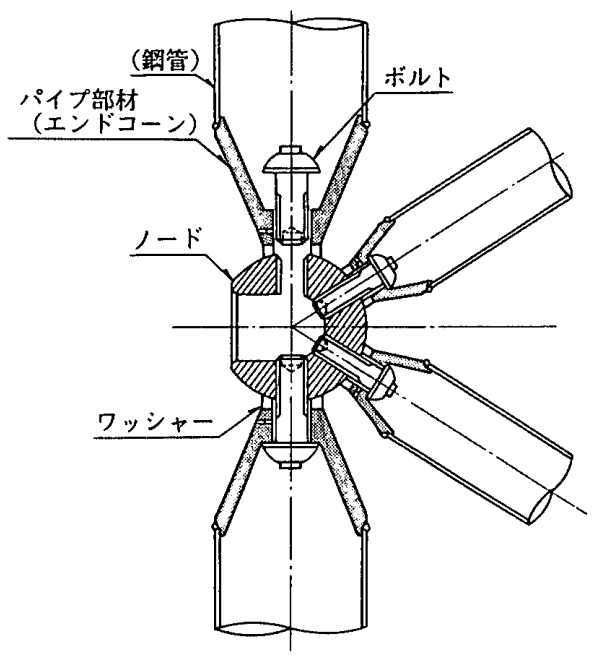

図一4 システムトラス部品 
れぞれ下から，27 m, $17 \mathrm{~m} ， 21 \mathrm{~m}$ の長さである。それ ぞれ正方形の組立材断面で, 使用部材はパイプと形鋼に よった。

また，防錆に関してはシステムトラス，コアシャフト， ゲインタワーは, $550 \mathrm{~kg} / \mathrm{m}^{2}$ の亜鉛メッキがなされ，耐 久性に対して万全を期している。

タワー鉄骨重量は，システムトラスが約 500 ton, コ アシャフトとゲインタワーの鉄骨が約 500 ton であり, 計 1000 tonであった。なおシズムトラス部品として， パイプは 114. $3 \phi \times 3.5 \sim 406.4 \phi \times 19$ (STK 400), ボル トはM27〜M95. (F 9 T 相当), ノード径は $230 \mathrm{~mm}$ $490 \mathrm{~mm}$ (SM 490 A 相当）を使用した。

\section{5 パイプ部材の自励振動}

細長い部材に風があたると, カルマン渦が発生し, 風 之直交方向に交番の力を受け振動が励起される。

このタワーのシステムトラスの水平材は, 風や地震に 対してあまり力を受けないので，経済性を考えて形状を 保つのに足りる程度の細長い部材（パイプは114:3 $3.5 \sim 139.8 \phi \times 6.0$ ，ボルトはM27〜M33）を使用して いる。このために，水平材の固有振動数は $7.4 \mathrm{~Hz}-7.9$ $\mathrm{Hz}$ であり，15 m/s 程度の風速で自励振動によって高域 の両振幅交番灾力が発生し, 部材あるいはボルトが疲労 破壊するおそれがある”。この対策として，部材をワイ ヤー等で固定する，部材の剛性を上げる，各種フィンを パイプ表面につけて気流を乱す，あるいはパイプにモル タル等を充填して減衰性を向上させるなどの方法が考え られる。このタワーでは, 美観上の問題もあり，モルタ ルを充填する方法を採用した。パイプにモルタルを充填 すると，質量が増加して，負の空力減衰が減少し；渦励 振による不安定現象を回避させることができる。

\section{6 柱脚部の設計}

垂直材，斜材からのすべての応力は，柱脚部の 12 個 のノードに集まる。これらのノードは,数枚のリブプレ一 トを介してベースプレートに溶接接合されている。水平 力に対して，タワーは巨視的には片持ち梁であり，この タワーのすべての安全性はこの 12 力所の柱脚部で受け 持つことになる。タワーの倒壊に対する危険回避のため に，柱脚部の設計にあたって，いわゆるフェイルセイフ の考え方を持ち込んだ。すなわち，溶接，アンカーボル ト部分のディテールとしての信頼性, 材料安全率による 安全の確保のほかに，太径ボルトを用い，システムトラ スのノードとベースプレートを直接に接合した。このこ とにより，溶接接合がたとえ破壊しても，溶接接合と同 等以上の耐力を有する太径ボルト接合により，ベースプ レートとの接合が保たれるという，二重の安全性を与え た。

\section{5. 風洞実験}

大連 TVタワーは特殊な形状および構造特性を有す ることから，耐風設計が重要なポイントとなる。そのた めの風洞実験を行った。

5.1 実験目的

タワーの設計用風荷重を得るために次の 2 種類の風洞 実験を行った。

(1) Pressure Model による静的風圧力の测定

(2) Base Balance Model によるベースモーメントの

测定

またタワー周辺の地形を再現し, 山頂の風速加速効果に ついても検討を行った。

\section{2 実験用模型}

実験用模型 (写真一 2 ) の縮尺は $1 / 300$ とし，速度の 縮尺は $1 / 2$ とした。システムトラスの変形モードを直線 と仮定することにより，模型は，Bace Pivot を持つ剛 な模型とし，剛性および慣性モーメントを調節した（図 一5)。模型のベーズでの回転剛性は $7.94 \times 10^{2} \mathrm{Nm} / \mathrm{rad}$ であり，これを実際のタ.ワーに換算すると, $8.58 \times 10^{10}$ $\mathrm{Nm} / \mathrm{rad}$ となる。これは，実際の夕ワーにおける設計外 カによるタワーの転倒モーメントとタワー頂部の変形角 との比加求めた値 $8.12 \times 10^{10} \mathrm{Nm} / \mathrm{rad}$ に近い值となっ ている。コアシャフトと展望階は, 軽量アクリル成型板 とし, コアシャフトは 6 角形を再現し, はく離および風 圧力を評価できるようにした。システムトラスは,スチー

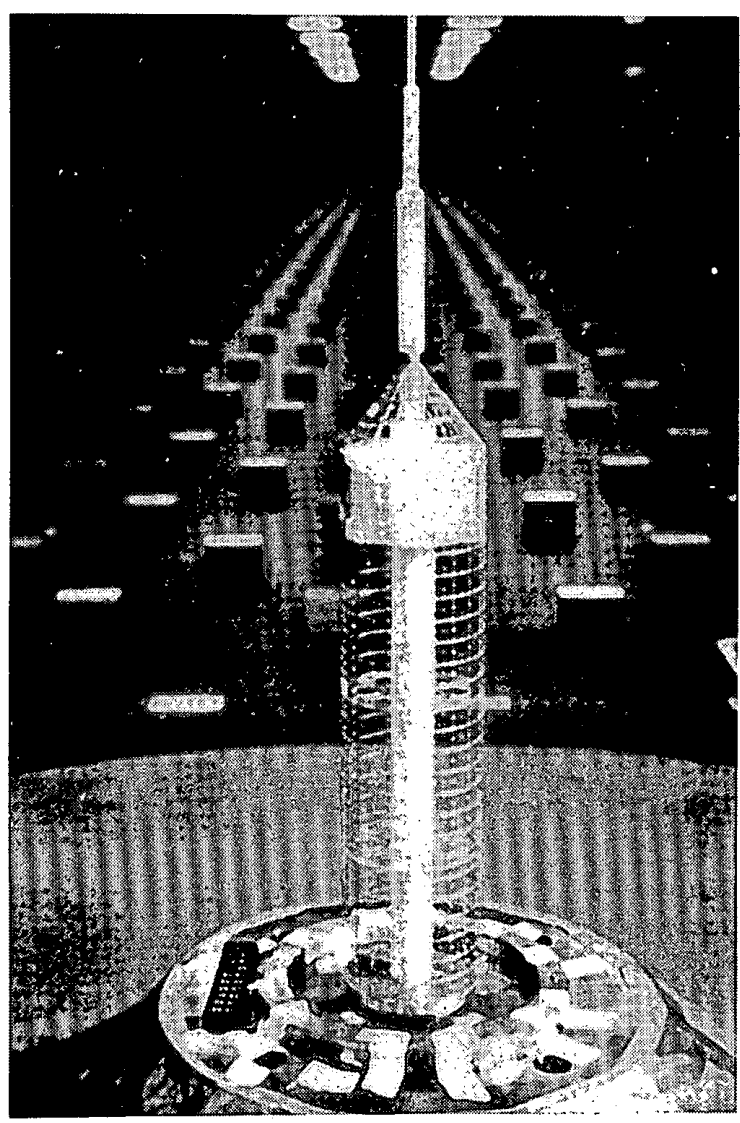

写真一2 風洞実験 


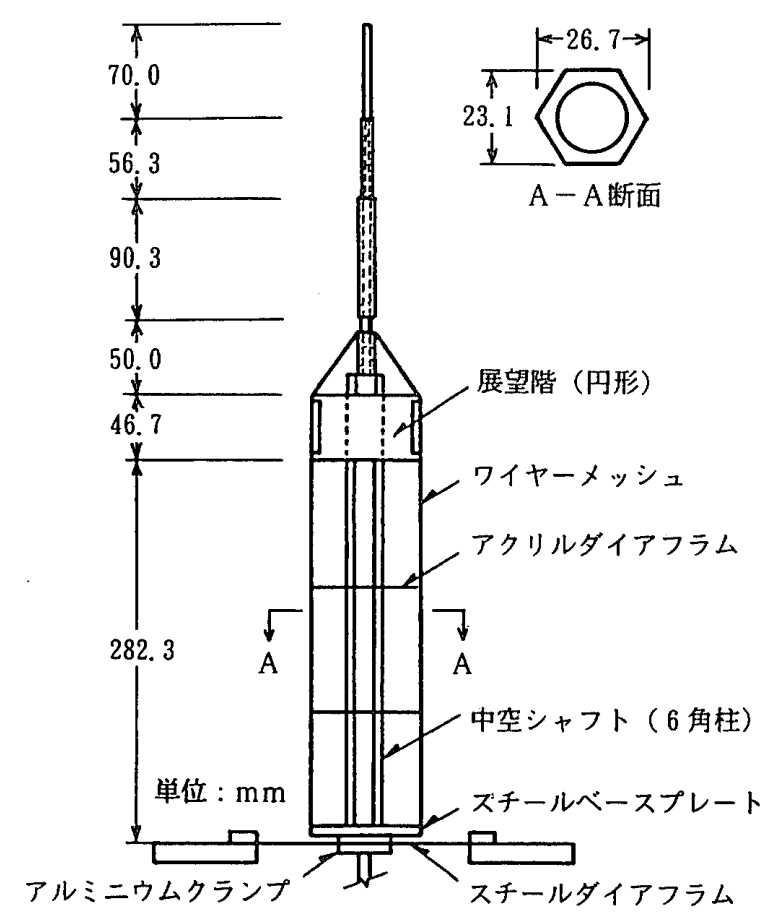

風洞実験用モデル

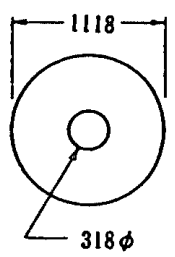

丘校の断面形状

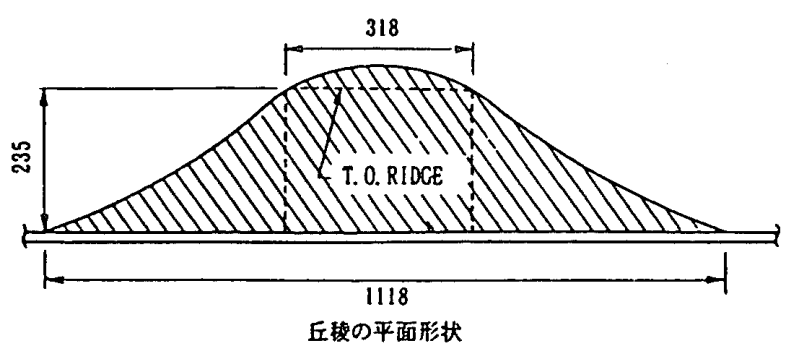

図一5実験用モデル

ルワイヤーでモデル化し，空隙率を実際のトラスと合わ せ, ゲインタワーは 3 本のアルミ管でモデル化し, 剛性 を一致させた。またこの管に円形の成形板を取付け，空 力弾性応答を合わせた。丘陵による局部的な風速の上昇 を実験に反映させるため, 円形で対称形の丘のモデルを 用いた。

\section{3 実験方法}

1）鉛直方向の平均風速および乱れの強さ

鉛直方向の平均風速および乱れの強さは“Open Country”および “Suburban Exposure”の 2 種類の地 表面粗度で熱線風測計により測定した。測定は丘陵の前 方 (ベース部の幅の 2 倍) と上部で行った。丘の動的な 粗度を調節するために，丘の表面に砂をまいた。

2）静的風圧力の測定
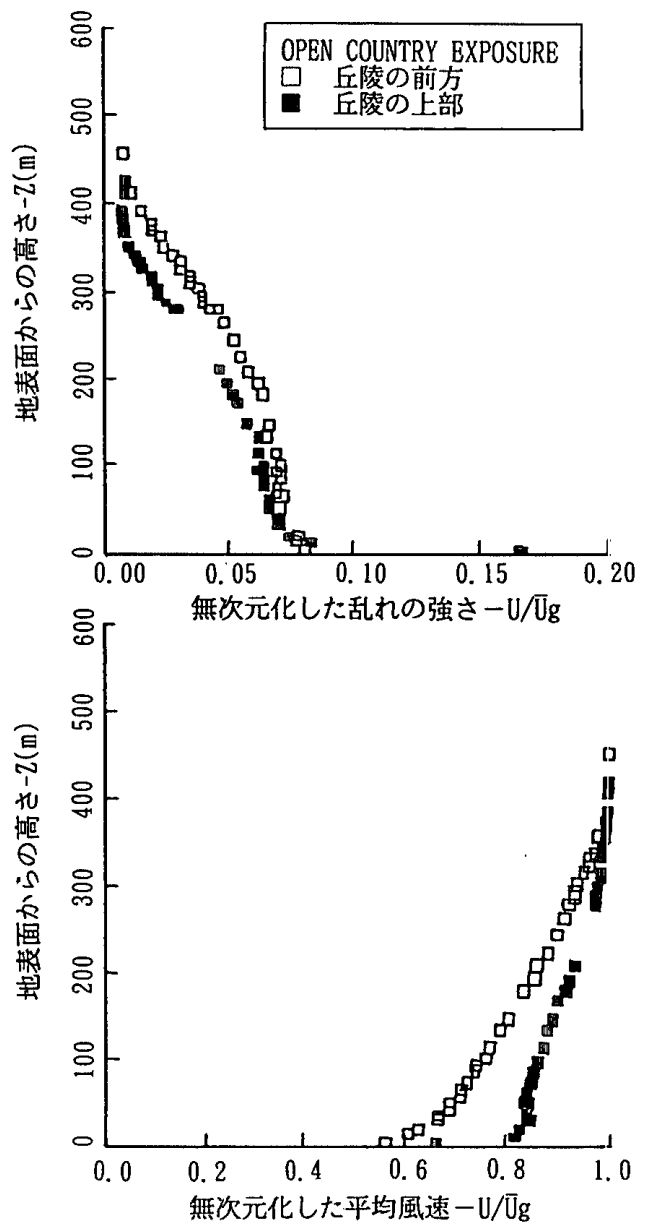

図一6 鉛直方向乱れの強さおよび平均風速分布

速度圧の測定は，丘陵の影響を考虑し，2 種類の地表 面粗度で行った。速度圧は, $0^{\circ}$ から $180^{\circ}$ を $15^{\circ}$ ピッチ でそれぞれ 150 分間ずつ測定した。

3）動的試験

動的試験は, Base Balance Modelにより，2 種類の 地表面粗度で, 平均傾度風速 $0 \sim 47 \mathrm{~m} / \mathrm{s}$ の範囲で 20 の 異なる速度で, 最大, 最小, 平均および RMS ベースモ一 メントの測定を行った。またアンテナ部の速度王および タワー部のベースモーメントについて $0^{\circ} \sim 180^{\circ}$ の範囲 で $45^{\circ}$ ピッチで測定を行った。

\section{4 実験結果}

1）鉛直方向の平均風速および乱れの強さ

Open Country Exposure での丘陵の前方および丘の 上での鉛直方向の平均風速および乱れの強さの分布を図 一6に示す。平均風速は丘の上で，かなり上昇し，高さ $50 \mathrm{~m}$ でこの上昇は $30 \%$ に達する。丘の上での勾配の 急激な変化により，地表面より $10 \mathrm{~m}$ までにはく離現象 が見られる。図一6でこの範囲に高い乱れの強さがでて いることでわかる。10 $\mathrm{m}$ 以上では乱れの強さは，高さ 方向にほぼ一定で約 $7 \%$ であった。

2）風力係数

コアシャフト部分の抗力係数は, 高さ方向にほぼ一定 の 0.60 であり，展望階では 1.05 であった。 

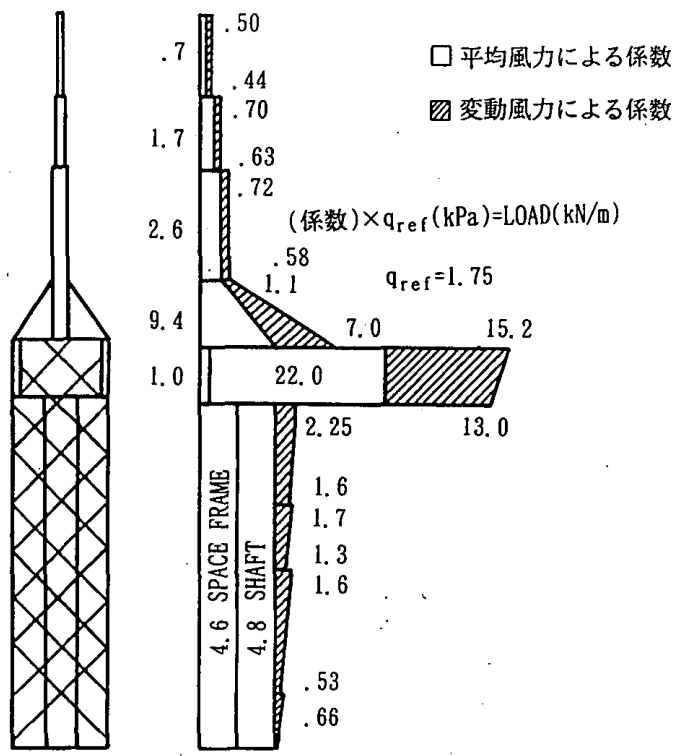

図一7 設計用風荷重

3) ベースモーメント

風速 $47 \mathrm{~m} / \mathrm{s}$ での平均ベースモーメントは $110 \mathrm{MNm}$ であり, 最大動的ピークモーメントは $50 \mathrm{MNm}$ であっ た。この值は風の方向によってはあまり変化しなかった。 4）丘陵の影響で速度圧は, 上昇したが, 動的倍率は適 度な值であり，全体のガストファクターは 1.45 であっ た。この理由として有効な空力弾性減衰の効果が考えら れる。この低いガストファクターは，平均風速の上昇に より風の乱れの上昇が伴わないことによる。

5)'タワー下部の速度圧の測定により, タワー下部の風 圧力は，システムドラスとコアシャフトでほぼ等しいこ とがわかった。

6）渦励振による横方向の励起は見られなかった。

7）静的および動的風洞実験より大連タワーの設計用風 荷重を図一7のように設定した。

\section{6. 安定解析}

部材の設計は弾性解析で行ったが，ここでは，有限変 形を考慮した弾塑性解析 ${ }^{8}$ により, 本構造の安定性を検 討した。

\section{1 解析方法}

1) 解析モデル

解析モデルはシステムトラス部分の架構を対象にモデ ル化した。図一8に解析モデルの立面図を示す。

2) 荷 重

固定荷重は全節点に割り振り，風荷重は図一7に示す 分布におおむ权従い，外周部の節点に載荷した。

載荷方法としては, 固定荷重を与えた後, 風荷重はそ の分布形状を保つようにしつつ, 次第に增加していった。

3）解析に用いた部材の軸力-軸変形関係

部材の軸力-軸変形関係は, 引張側ではバイリニアと し, 圧縮側では, 有限変位理論を用いて行った部材の弾
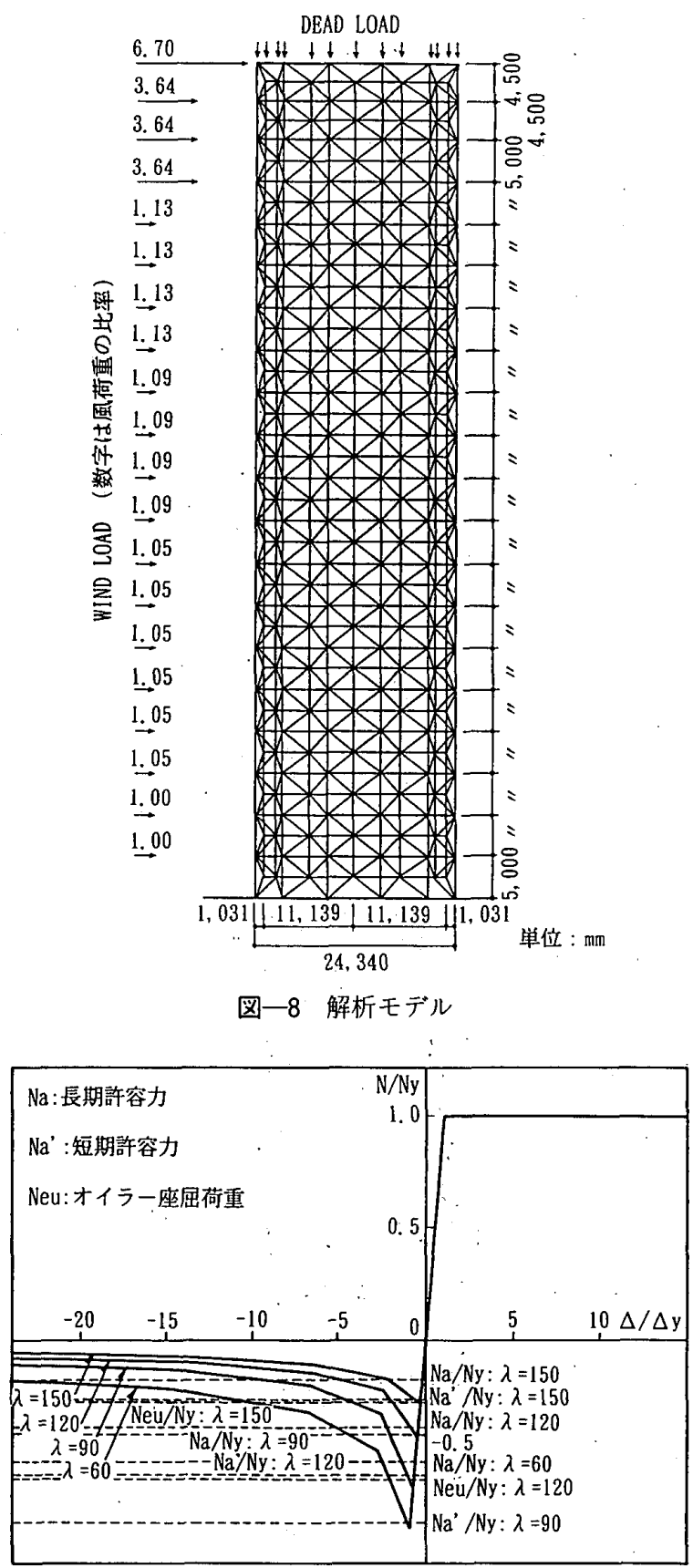

図一9 軸力ー軸変形関係

塑性解析より求めた座屈曲線をもとに，区分線形化した 関数を用いて近似的に表した。

“細長比; $\lambda=60,90,120,150$ の部材についての軸力軸変形関係を図一9に示す。

4) 解析手順

部材の軸力之軸変形の関係に引張降伏と圧縮による座 屈現象を考慮したモデルを用い，節点の座標を各ステッ プごとに移動させる有限変位理論に基づいた。

6.2 解析結果

1) 外力-変位関係

解析結果として, 頂部の風荷重方向の外力-变位関係 を図一10に示す。

2) 解析結果の概要 

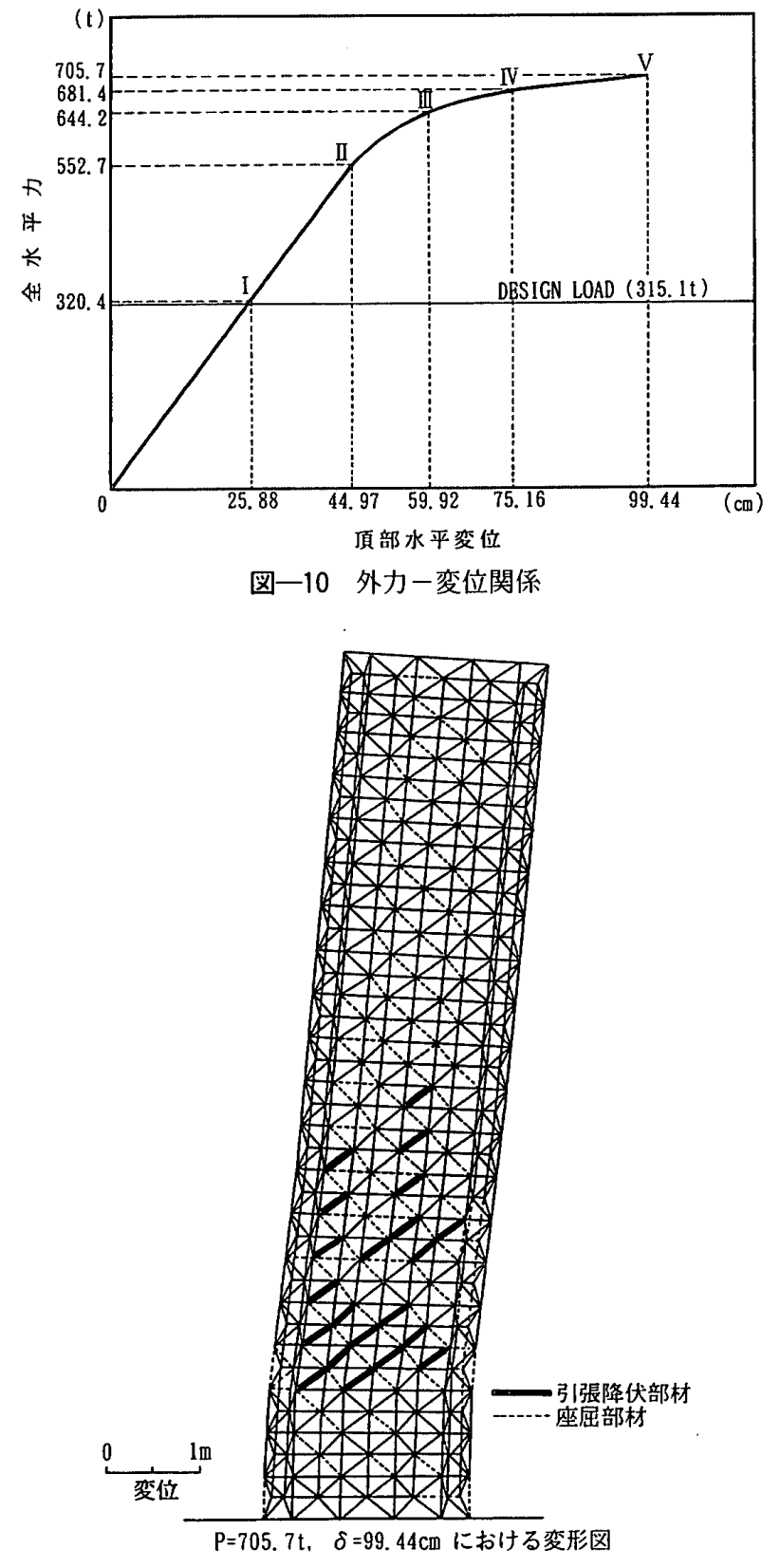

図一11 変形図

（1）設計荷重レベルでは，当然のことではあるが，全 体は弾性状態にある。この状態は，鉛直荷重を載荷した 上に，設計用風荷重の約 1.6 倍まで続く。

（2）設計用風荷重の約 1.7 倍を超えるころから圧縮材 の座屈が始まり, その後引張材も降伏するが, 全体の荷 重変位関係は低下することなく上昇を続ける。最頂部の 変位が $1 \mathrm{~m}$ に達するところまで解析を行ったが（図一 11)，その時の水平力は設計用風荷重の 2.24 倍となって いる。

（3）本構造は部材数が非常に多く, 円筒形状であるた め, 各部材の座屈現象は同時には発生しない。そのため 座屈した部材の耐力低下を他の部材が補うことができる ため,ここで行った解析の範囲では, 全体の荷重-変位 関係には下り勾配は生じない。
（4）外面トラスと内面卜ラスの間隔が小さいため, 円 筒形の断面が不安定になるという心配があったが，ここ で行った解析によると, 個材座屈および降伏現象が先行 し，全体的な不安定現象は起きなかった。最終的な状態 では円筒形断面が，やや棈円状に変形しているが $24 \mathrm{~m}$ の元の直径に対して直径の変化量は $6.5 \mathrm{~cm}$ 之非常に小 さい。

\section{7. 材料と強度}

7.1 システムトラス部品

1) 材料之許容応力度の考え方

1-1) 材料 ;

部品の材質を表一1に示す。

1-2）許容応力度；

許容応力度の基本的な考え方は, 日本建築学会の鋼構 造設計基準に基ついているが，前述したようにここで 設定した風荷重の危険確率が大きいことを考慮して, 短 期の許容応力度を長期許容応力度の 1.25 倍とした。

2）接合部の設計方針

2-1）強度のバランス,

ここで用いているシステムトラスの接合11,61では，接 合部の強度をパイプ部材の引張強度や圧縮強度より大き くすることを基本にしている。システムトラス接合部の 各部品（ボルト，ノード, エンドコーン）のサイズ体系 は，ISO と JIS 規準にならったボルトのサイズ体系を 基準としている。ノードの許容応力は, 各パイプからの 軸力の組み合わせによるノードの許容応力の低下を考慮 し, 各サイズに許容される最大のボルトサイズの約 1.6 倍である。この最大対応ボルトの破断が生じる前にねじ 拔けを生じさせないように，羽じの必要かみあい長さを 一般の高力ボルトのナット高さに比べて大きくしてい る。またエンドコーンの許容応力は, 圧縮応力時も考慮 し, 各サイズに許容される最大のボルトサイズの 1.2 倍 としている。さらに, ボルトの破断が生じる前に, エン ドコーンの破壊が生じないようにしている。

\section{2-2) 疲 労}

接合部の実大実験により，システムトラス接合部の疲 労強度は、ボルトの疲労強度に等しいことが分かってい る9!。ボルトの有効断面積に対する $S-N$ 線は次式のよ うに表せる。

$$
\log S=-0.300 \log N+2.58
$$

表一1 部品の材質

\begin{tabular}{|c|c|c|}
\hline 部 品 名 称 & 該 当 規 格 & 仕 \\
\hline J & JIS G 3106 & SM490A 相当 \\
\hline エンドコーン & JIS G 3106 & SM $490 \mathrm{~A}$ 相当 \\
\hline ハீ & JIS G 3444 & STK 400 \\
\hline ボル & JIS B 1186 & $\begin{array}{l}\text { F9T 相当 } \\
\text { 特殊形ルト }\end{array}$ \\
\hline
\end{tabular}




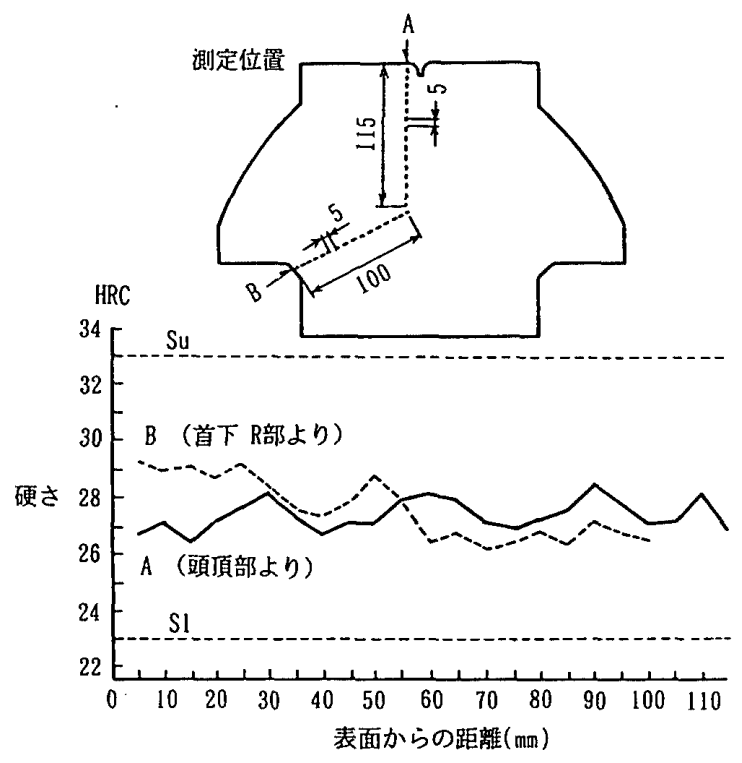

図一13 内部硬さ試験の結果（2）

であることが分かった。

\section{8. 施工技術}

施工に当たって，屋根構造として多く用いるシステム トラスをタワー構造物に対して適用することが課題で あった。そのため, 対じれ，傾き等に関する精度の確保 およびボルトの締付に関する品質管理を検討した。

\section{1 施工計画}

1) 建方計画

建方の基本サイクルを下記のように定め，建方を行っ た。

（1）コアシャフト鉄骨をシステムトラスより 2 節（20 m）先行して建て, 揚重機を上方へ盛り替えシステムト ラスを建てる。

（2）システムトラスは縦材 1 本と斜材 2 本の計 3 本を 地組みしたものを建込み単位とする。

（3） 1 段 12 組を建て込み後水平材を取り付ける。

（4）ボルトの締込みは建込みシステムトラスの 2 段下 より後追いする。

2）揚重機計画

揚重機はコアシャフト鉄骨に添って 3 基配置し，各々 平面角 $120^{\circ}$ の範囲を分担する。各揚重設備は, 支柱, ブー ムおよびブーム等の盛り替え用りフターにより構成され

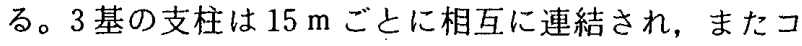
アシャフト鉄骨にもステーがとられ，揚重時の曲げに耐 えられる構造となっている。各揚重機には 3 台の電動 ウィンチと 2 台の手巻ウィンチが地上面に配置されブー ムの上げ下げ，荷巻，揚重機盛り替えを行う。

\section{2 品質管理}

システムトラスを本タワーのように，平面的に閉じて おり高さ方面にしか逃げのとれない構造物に用いた場 合, 部材精度や建方順序が建方精度に与える影響は全く
未知であった。

1) 管理項目, 管理目標値

完成体の精度確保のため，建方途中におけるシステム トラスに対する管理項目，管理目標值を次のように定め た。

（1）円周方向のねじれおよび各段ごとの折れ曲がり： 各段ごと $24 / 20000$ かつ全体 24/99000

この目標値は，ノード中心部にあけた穴径が $24 \mathrm{~mm}$ であったため，この穴径を基準にして，ずれを測定する ことが実用的であったためである。

（2）同一段のノードとノード間の相対レベル差：4 $\mathrm{mm}$ 以内

2）管理サイクル

システムトラスの各精度はボルトをスナグタイトで締 め込んだ状態で確認する必要がある。図一14 に示すよ

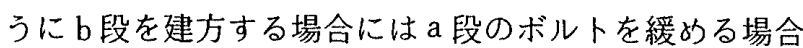
があるため，構造体の倒れ，ねじれ，レベルを正確に確 認できるのは $\mathrm{c}$ 段の建方時となり，a段にて生に゙た目標 值を超える誤差の調整は c 段またはd 段で行うことにな る。よって 3 段を一単位とした管理・調整サイクルを採 用した。

\section{3）建方精度の調整}

すべての建方誤差は節点間距離の誤差によって生じ る”。したがって節点間長さの調整により補正すること とし, 具体的方法として, 各縦材および斜材のワッシャ に対応したシムプレートを準備しプラス方向への調整が できるようにした。また 3 段ごとにマイナス調整ができ るよう, 標準ワッシャより薄手のワッシャを準備した。 4）建方精度

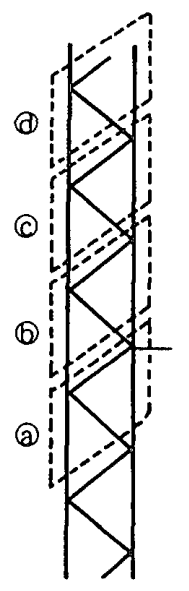

管理サイクル

図一14 管理サイクル

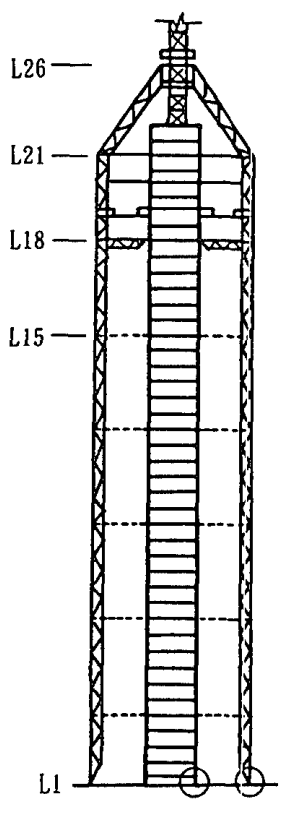

筒体レベル

図-15 高さレベル 


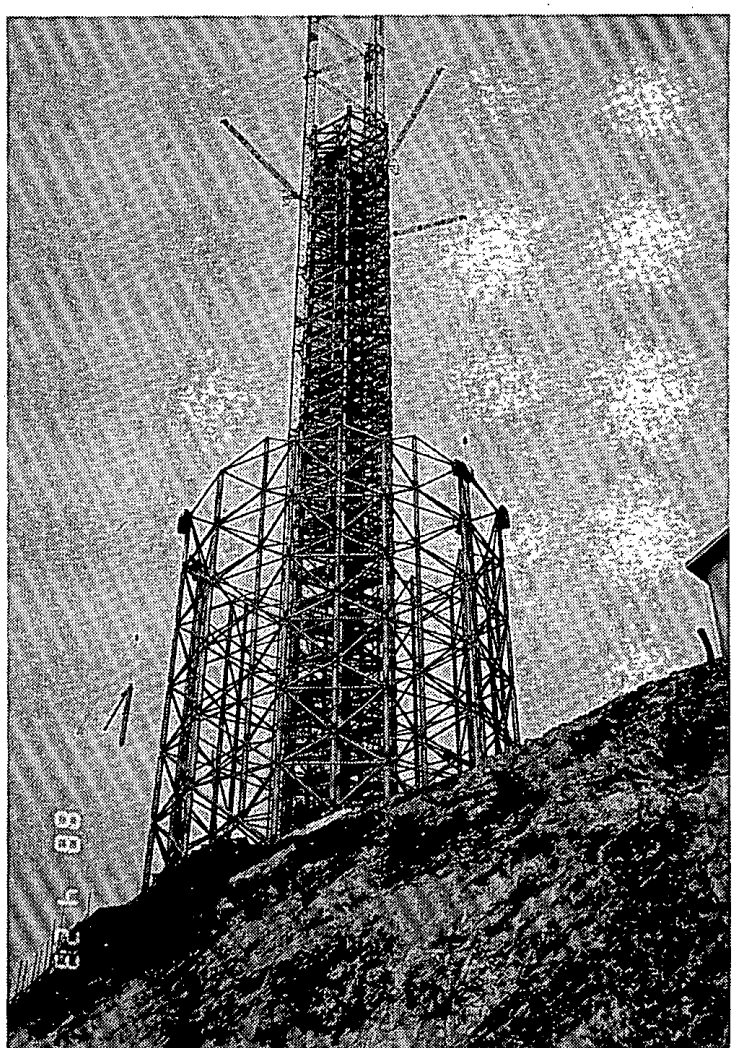

写真一3 建設中のタワー（1）

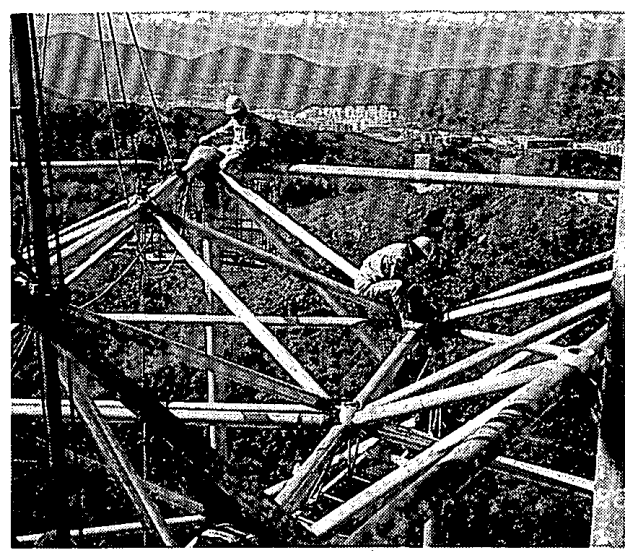

写真一4 建設中のタワー（2）

倒れ，ねじれについては各段ごとに管理目標値を大き く下回り, 非常に精度よく, 水平材の建て込み, 次段の システムトラスのボルト取りに支障をきたすことはほと んよ゙なかった。ただし，図一15に示す L-18 以上のコ アシャフト鉄骨と取合いのある段では，倒れ補正を優先 した結果, 取合い側の抱束もあり水平材を中心にノード 〜エンドコーン間に肌隙が生じる確率が增した。なお， 倒れ調整，肌隙調整のためにシムプレートを挿入したの は計 61 力所であったが，これは全体ジョイント数の 1.2 \%と非常に小さな割合である。またコアシャフト鉄骨

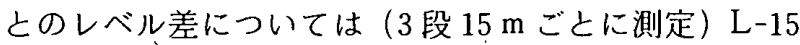
で最大 $20 \mathrm{~mm}$ 生じたため, L 16 L 17 の 2 段にわたり 薄手ワッシャにてレベル調整を行った。また完成後のシ ステムトラス軒部 $(B L+99 \mathrm{~m})$ での倒れは，互いに直
交する 4 点で各々 $20,10,10,10 \mathrm{~mm} ゙$ あった。

5) 工 程

システムトラス，コアシャフト鉄骨およびゲインタ ワーの建方は, ' '87.10.15 '88.8.12（内'88.1.7〜4.10 冬期中断）の 209 日間であった。うち気像条件による作 業不能日を除く実作業日数は 161 日 $(77 \%)$ ，システム トラス建方に要した日数は 66.5 日 (3 班作業)であった。 写真一 3 と 4 は建設中のものである。

8.3 ボルトの締付け管理

システムトラスのボルト締付け管理は, 締付け完了時 において,ノード〜ワッシャ間, エンドコーンーワッシャ 間およびボルト頭部〜エンドコーン内面間に肌隙を生じ ないこと(スナグタイトの状態)を管理規準としている。 ボルト肌隙をなくすまで締め,軸力導入は行わなかった。 なお,肌隙のチェックはノード〜ワッシャ間,エンドコー ンーワッシャ間は目視にて，またボルト頭部〜エンド コーン内面間は,エンドコーンに設けられた検查孔より， 光学内視鏡にて全数検查を行った。

\section{9. 結 び}

定形化された構造設計から脱皮した一つの海外プロ ジェクトを例に，設計・製作・施工の一連の行為，およ び，その中で行った技術開発について報告した。

本報告で論述した主な項目は次のとおりである。

1）システムトラスのタワーへの適用

屋根構造として多く用いるシステムトラスを, 本格的 なタワーに対して適用した。この適用にあたり, 設計・ 加工・施工上の課題として, 以下の重点項目の検討を 行った。

2）荷重および許容応力度の設定

荷重に対して不確定要因が残る中国・大連市における タワーの設計に必要な荷重の組合せや許容応力度を定め た。

3）部材設計上の特殊課題の解决

外部むき出しのシステムトラスに対する防錆, および, 外部むき出しパイプ部材に対する自励振動を検討し，ま た, 柱脚の設計にはフェールセーフの考えを持ち込んだ。

4）風洞実験の実施

風洞実験により，丘陵の影響を考慮したタワーの設計 用風荷重を決めた。

\section{5）構造材の安定性の確認}

有限変形を考慮した弾塑性解析により，圧縮材の座屈 や引張材の降伏を踏まえた, タワーの最終的な状態を確 認した。

\section{6) 加工上の検討}

JIS に規定のないサイズの太径ボルトの仕様を，製造 実験に基づき，定めた。

7）施工上の検討 
システムトラスをタワーに適用する施工法の一つを確 立した。

\section{謝 辞}

大連 TVタワーの意匠設計は，株式会社日建設計の 松本晃吉氏と亀井忠夫氏によってなされました。また新 日本製鐵株式會社の矢崎光彦氏と黒川輝哉氏には，施工 技術の研究をして頂きました。このプロジェクトにかか わった人々は, 営業のスタッフ, 商社としての三井物産, 施主としての大連テレビ局, 工事に関係した中国の人々 等，100名を超えます。そのすべての方々に深く感謝致 します。

風洞実験を指導して頂いたカナダのウエスタン・オン タリオ大学の風工学研究所教授・A.G. Davenport 博 士，および太径ボルトの仕様决定に際して, 貴重な御助 言を頂いた大阪大学教授 ·脇山広三博士に深く感謝致し ます。

\section{参考文献}

1）川合広樹, 岩田 衛, 白井貴志：システムトラス構法計 画成立に関する論証, 日本建築学会計画系論文報告集, 第 390 号, pp. $51 \sim 59,1988$ 年 8 月
2) 日本建築学会：建築物荷重指針・同解説，1981 年 11 月

3）日本建築学会：鋼構造設計規準，1970 年 5 月

4) 日本建築学会：鋼構造限界状態設計規準 (案) - 同解説, 1990 年 2 月

5）日本建築センター：構造計算指針・同解説，1988 年 5 月

6) 岩田 衛, 和田 章, 大場高秋, 白井貴志: 部品構成さ れた鋼管立体トラスの接合部の回転性能に関する研究, 日本建築学会構造系論文報告集, 第 391 号, pp. 45 58, 1988 年 9 月

7) 大熊武司: 強風に上る鎆構造物骨組の累積疲労損傷, 配 管技術, 日本工業出版, 1989 年 5 月

8) 和田章, 久保田英之: 部材の座屈および破断点考慮し たトラス構造の崩壊解析, 日本建築学会構造系論文報告 集, 第 396 号, pp. 109 117, 1989 年 2 月

9）岩田 衛, 和田 章, 白井貴志：太径ボルトを用いたシ ステムトラスの疲労実験, 日本建築学会構造系論文報告 集, 第 422 号, pp. 123 134, 1991 年 4 月

10）脇山広三, 宇留野清, 岩田 衛, 川合廣樹, 白汼貴志： 高強度太径ボルトM200の製造に関する検討，日本建築 学会大会学術講演梗概集 (関東), pp. 927 928, 1988 年 10 月

(1991 年 9 月 10 日原稿受理, 1992 年 2 月 6 日捊用決定) 